\title{
Kualitas Pupuk Cair Organik dengan Kombinasi Limbah Ampas Jamu dan Limbah Ikan
}

The Quality of Liquid Organic Fertilizer with Combination of Herbal Drink (Jamu) and Fish Wastes

\author{
Jumirah $^{1 *}$, A. Wibowo Nugroho Jati ${ }^{1}$ L. Indah Murwani Yulianti ${ }^{1}$ \\ ${ }^{\text {I}}$ Fakultas Teknobiologi, Universitas Atma Jaya Yogyakarta, Yogyakarta \\ Email: irajumira06@gmail.com *Penulis untuk korespondensi
}

\begin{abstract}
Liquid organic fertilizer is one of organic fertilizers in liquid form, as nutrients source for plants. Liquid organic fertilizer can be made from waste materials organic, such as home industry daily wastes. Materials that used in this research was jamu production and fish wastes. Objective of this reasearch were to identify how much the percentage degree of carbon $(C)$, nitrogen $(\mathrm{N})$, phospor $(\mathrm{P})$, potassium $(\mathrm{K})$, calcium $(\mathrm{Ca})$, iron $(\mathrm{Fe})$, and magnesium $(\mathrm{Mg})$ compared to SNI-19-7030-2004 and Permentan/SR.140/10/2011 standards, and also to find the characterization of bacteria present in liquid organic fertilizer. Liquid organic fertilizer in this research was made by anaerobic fermentation for 28 days, used 5 treatments with different amount of materials, i.e. $100 \%$ of jamu waste, $100 \%$ of fish wastes, and both jamu waste and fishes waste with percentage ratio $50 \%-50 \%, 25 \%-75 \%$, and $75 \%-25 \%$. Percentage of nutrient composition in liquid organic fertilizer were carbon (C) $2,3474-4,8397 \%$; nitrogen (N) $0,047-$ $\mathbf{0 , 3 5 3 7 \%}$; phospor (P) 0,0343-0,2433\% ; potassium (K) 0,1867-0,2433\% ; calcium (Ca) 0,0204$0,0777 \%$; iron (Fe) 0,0019-0,0003\%; and magnesium (Mg) 0,0129-0,02008\%. Bacteria that were found in liquid organic fertilizer were bacterial isolates resembling characters bacteria genus Lactobacillus sp., Psudomonas sp., Bacillus sp., Zymomonas sp., Staphylococcus sp., Actinobacillus sp., Cellulomonas sp., and Acetobacter sp.
\end{abstract}

Keywords: liquid organic fertiilizer, fish and jamu wastes, fermentation, fertilizer bacteria

Abstrak

Pupuk cair organik merupakan salah satu jenis pupuk organik berbentuk cair yang berfungsi sebagai sumber nutrisi bagi tanaman. Pupuk cair organik dibuat dari bahan organik limbah rumah tangga. Bahan organik yang digunakan dalam penelitian ini adalah limbah ampas jamu dan limbah ikan. Tujuan penelitian ini untuk mengetahui seberapa besar kadar unsur hara karbon $(\mathrm{C})$, nitrogen $(\mathrm{N})$, fosfor $(\mathrm{P})$, kalium $(\mathrm{K})$, kalsium $(\mathrm{Ca})$, besi $(\mathrm{Fe})$, dan magnesium $(\mathrm{Mg})$ yang dibandingkan dengan standar SNI-19-7030-2004 dan Permentan/SR.140/10/2011, serta karakterisasi bakteri yang ada dalam pupuk cair organik. Pembuatan pupuk cair organik dalam penelitian ini menggunakan metode fermentasi secara anaerob selama 28 hari dengan lima perlakuan yaitu 100\% limbah ampas jamu; 100\% limbah ikan; dan perbandingan limbah ampas jamu dan limbah ikan sebesar 50\%:50\%; 25\%:75\% dan 75\%;25\%. Hasil pengukuran kadar unsur $C$ sebesar 2,3474-4,8397\%, unsur $N$ sebesar $0,047-0,3537 \%$, unsur $P$ sebesar 0,0343-0,2433\%, unsur K sebesar 0,1867-0,2433\%, unsur Ca sebesar 0,0204-0,0777\%, kadar Fe sebesar 0,0019-0,0003\%, dan kadar Mg sebesar 0,0129-0,02008\%. Isolat bakteri yang ditemukan dalam pupuk cair organik yaitu isolat bakteri yang memiliki karakter menyerupai bakteri dari genus Lactobacillus sp., Psudomonas sp., Bacillus sp., Zymomonas sp., Staphylococcus sp., Actinobacillus sp., Cellulomonas sp., dan Acetobacter sp.

Kata Kunci : Pupuk cair organik, limbah ikan dan ampas jamu, fermentasi, bakteri pupuk 


\section{Pendahuluan}

Pupuk merupakan suatu nutrisi tambahan yang penting bagi pertumbuhan dan perkembangan tanaman. Beberapa jenis pupuk yang sudah dikenal oleh masyakarat yaitu pupuk organik yang berasal dari bahan organik baik berbentuk cair atau padat contohnya yaitu pupuk kompos dan pupuk anorganik seperti pupuk kimia (Santi, 2008). Pupuk kimia merupakan salah satu jenis pupuk yang masih diminati oleh petani Indonesia karena dianggap memiliki respon yang lebih cepat, tetapi penggunaan yang terus-menerus dapat menurunkan produktivitas lahan dan merusak struktur tanah serta berbahaya bagi kesehatan manusia (Dewi dkk., 2016). Oleh karena itu, dibutuhkan pupuk organik cair (POC) yang memiliki kelebihan memperbaiki struktur tanah, unsur hara dapat diserap tanaman dengan cepat, memperbaiki kehidupan biologi tanah, mengandung mikroorganisme, penerapannya lebih mudah, dan mengatasi defesiensi hara (Siboro dkk., 2013). Pupuk cair organik dapat dibuat dari bahan-bahan organik seperti limbah ampas jamu dan limbah ikan.

Limbah ampas jamu merupakan salah satu jenis limbah yang dihasilkan dalam pembuatan jamu yang biasanya hanya dibuang dan dibiarkan terdegradasi secara alami di lingkungan, dibiarkan kering dan dibakar sehingga berpotensi menyebabkan pencemaran lingkungan (Atmaka dkk., 2016). Limbah jamu berupa campuran dari ampas jahe, lengkuas, kunyit, dan temulawak yang masih mengandung zat aktif, mineral, dan gula sederhana serta kadar serat yang tinggi (Natalia dkk., 2016), sehingga berpotensi sebagai pupuk organik.

Limbah rumah tangga yang lain yaitu limbah perikanan seperti sisik, jeroan, dan insang yang merupakan limbah organik dengan kandungan protein, nitrogen, nitrat, dan nitrit yang cukup tinggi, sehingga sangat berpotensi sebagai pupuk cair organik (Ibrahin, 2005).

Kombinasi kedua bahan tersebut diharapkan dapat menjadi pupuk cair organik dengan kualitas yang baik. Proses pembuatan pupuk cair organik dibantu oleh mikoorganisme dekomposer yang mempercepat proses perombakan bahan organik sehingga dapat dengan mudah diserap oleh tumbuhan untuk kebutuhan hidupnya. Oleh karena itu, karakterisasi isolat bakteri pada pupuk tersebut juga penting untuk dilakukan.

\section{Metode Penelitian}

\section{Alat dan Bahan}

Alat yang digunakan dalam penelitian terdiri dari timbangan analitik, toples, selang, gelas ukur, $\mathrm{pH}$, termometer, spektrofotometer serapan atom Hitachi-Z-2000 Polarized Zeeman, serangkaian alat destilasi, autoklaf Hirayama Hiclave HVE50, LAF Airtech, inkubator RedLine, dan Inductively Couple Plasma Optical (ICP) Varian 715-Emission Spectrometry. Bahan utama berupa limbah ampas jamu, limbah ikan, molase, dan air cucian beras.

\section{Rancangan Percobaan}

Penelitian ini termasuk penelitian eksperimental yang menggunakan Rancangan Acak Lengkap (RAL) terdiri dari lima perlakuan dan tiga ulangan. Perlakuan terdiri dari $100 \%$ limbah ampas jamu, 100\% limbah ikan, perbandingan limbah ampas jamu dan limbah ikan (50\%;50\%, 75\%;25\%, dan 25\%:75\%). Analisis data menggunakan program ANOVA dan dilanjutkan dengan Duncan Multiple Range Test (DMRT) dengan aplikasi SPSS 15.0.

\section{Tahapan Penelitian}

\section{Preparasi Bahan Dasar}

Limbah ampas jamu dijemur dibawah sinar matahari selama 5 hari. Limbah ikan dibersihkan dahulu dari kotoran dengan cara dicuci bersih dan dipotong atau dicacah hingga berukuran 1-2 cm. Limbah ikan kemudian dijemur. Setelah itu diletakkan dalam wadah.

\section{Pembuatan Pupuk Cair Organik}

Limbah ampas jamu dan limbah ikan ditimbang sesuai perlakuan dan dimasukkan dalam toples gelap berukuran 10 liter, ditambahkan molase $100 \mathrm{ml}$ dan air cucian beras 5 liter. Toples ditutup rapat dan bagian penutupnya dibuat lubang kecil untuk diberi selang yang dihubungkan dengan botol plastik berukuran yang diisi air. Proses fermentasi dilakukan selama 28 hari. Setelah proses 
fermentasi selesai, tutup toples dibuka dan disaring untuk mendapatkan filtrat pekat yang akan diukur kadar unsur C, N, P, K, Ca, Fe, Mg, dan dilakukan karakterisasi bakteri.

\section{Pengukuran Parameter Pupuk Cair}

Parameter yang diukur meliputi suhu dan pH selama proses fermentasi setiap 3 hari sekali, serta pengukuran kadar unsur hara meliputi kadar nitrogen total dengan metode Kjeldahl, kadar karbon organik dengan metode Walkey dan Black, kadar kalium dengan alat flamefotometer, kadar fosfor dengan spektrofotometer, kadar besi dengan menggunakan spektrofotometer serapan atom, dan kadar kalsium dan magnesium dengan alat Inductively Couple Plasma Optical (ICP).

\section{Isolasi dan Karakterisasi Mikrobia dari Hasil Fermentasi Pupuk Cair Organik}

Isolasi mikrobia diawali dengan sampel pupuk cair dilakukan pengenceran mulai dari pengenceran $10^{-1}$ sampai $10^{-3}$ yang masingmasing diambil $0,1 \mathrm{ml}$ dan diisolasikan ke medium NA petri secara pour plate. Isolat yang didapatkan kemudian dilakukan pemurnian dengan metode steak plate.

Karakterisasi isolat bakteri yang telah murni diawali pengamatan morfologi koloni dilanjutkan dengan pengecatan Gram dan pengamatan morfologi sel, uji motilitas, uji katalase, dan uji biokimia yang meliputi uji fermentasi karbohidrat (glukosa, laktosa, sukrosa), uji reduksi nitrat, dan uji pembentukan indol. Hasil uji mikroba yang didapatkan kemudian dibandingkan untuk karakterisasi secara manual menggunakan buku Bergey's Manual of Determinative Bacteriology 7 th edition.

\section{Hasil Dan Pembahasan}

\section{pH dan Suhu Selama Proses Fermentasi}

Suhu dan $\mathrm{pH}$ pupuk cair organik selama proses fermentasi yang dapat dilihat pada Gambar 1.

Nilai $\mathrm{pH}$ pupuk selama proses fermentasi (Gambar 1) berkisar antara 4,5-5,7 dan cenderung meningkat hingga akhir proses fermentasi, tetapi $\mathrm{pH}$ masih dalam kisaran asam yaitu 4,2-6,3. Hal tersebut disebabkan aktivitas mikrobia yang merombak bahan organik seperti karbohidrat, protein, dan lemak menjadi asam organik (Dwicaksono, 2013 dalam Sundari dkk., 2014).

Proses perombakan bahan organik juga menghasilkan gas $\mathrm{CO}_{2}$ dan asam karbonat $\left(\mathrm{H}_{2} \mathrm{CO}_{3}\right)$ yang mampu menurunkan $\mathrm{pH}$ akibat ion $\mathrm{H}^{+}$yang dilepaskan (Handayani dkk., 2015). Adanya peningkatan $\mathrm{pH}$ dikarenakan volume amonia yang terus bertambah di lingkungan akibat proses perombakan (Yuwono, 2007 dalam Aditya dkk., 2015).

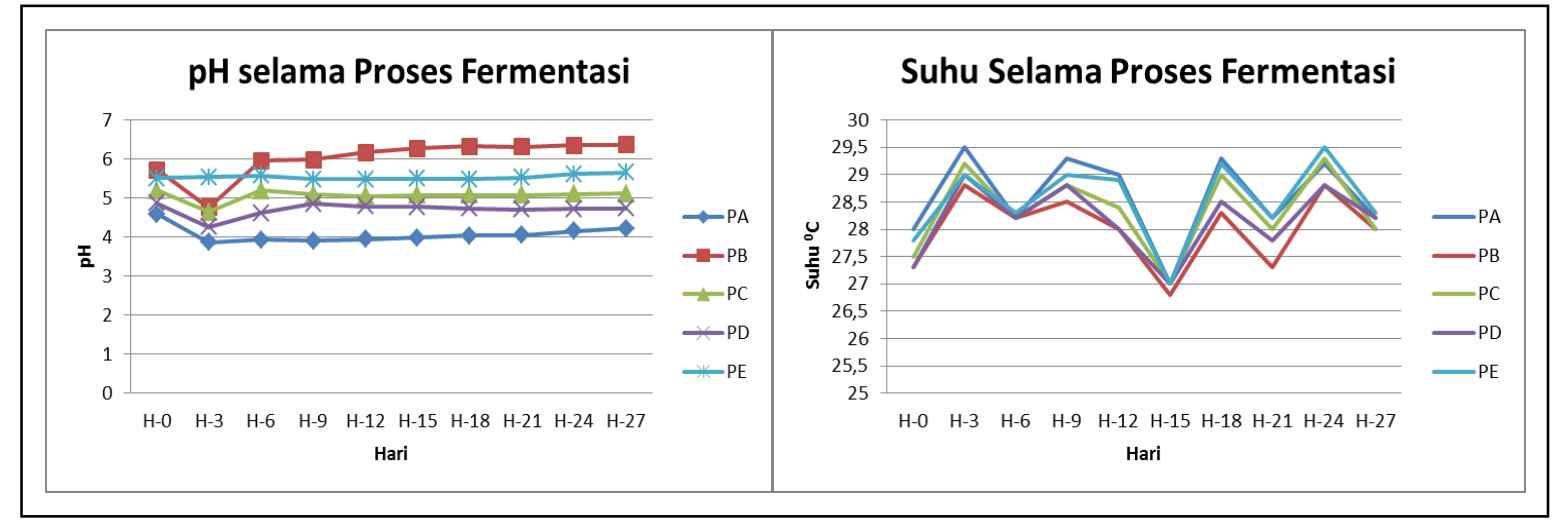

Gambar 1. pH dan suhu pupuk cair organik kombinasi limbah ampas jamu dan limbah ikan selama proses fermentasi 
Suhu terendah ketika proses fermentasi yaitu $26,8^{\circ} \mathrm{C}$, sedangkan suhu tertinggi yaitu $30^{\circ} \mathrm{C}$. Suhu tersebut masih diambang batas normal suhu lingkungan yaitu $20-27^{\circ} \mathrm{C}$. Hal ini dipengaruhi oleh kondisi lingkungan sekitar seperti cuaca dan adanya reaksi eksotermik akibat proses degradasi bahan organik yang dilakukan oleh mikroorganisme (Sutanto, 2002).

Kenaikan suhu selama proses fermentasi tidak terjadi secara signifikan yaitu hanya mencapai suhu $30^{\circ} \mathrm{C}$, meskipun termasuk dalam suhu yang baik untuk proses fermentasi tetapi pada suhu tersebut proses dekomposisi bahan organik belum terjadi secara maksimal sehingga waktu yang dibutuhkan untuk proses fermentasi menjadi cukup lama (Indriani dkk., 2013).

\section{Hasil Analisis Unsur Hara}

Hasil pengukuran kadar unsur hara dapat dilihat pada Tabel 1 .

Berdasarkan data (Tabel 1) kadar unsur karbon (C) pada semua perlakuan masih belum memenuhi standar minimal baku mutu pupuk organik berdasarkan SNI-19-7030-2004 $(\leq 9,80 \%)$. Unsur karbon terendah dimiliki pupuk perlakuan PB yaitu 2,374\%, sedangkan kadar tertinggi dimiliki pupuk perlakuan PE yaitu $4,840 \%$.
Kadar karbon yang rendah disebabkan adanya proses degradasi bahan organik kompleks seperti selulosa dan hemiselulosa yang membutuhkan waktu cukup lama. Mikroorganisme pendegradasi juga membutuhkan senyawa karbon sebagai sumber energinya untuk degradasi bahan organik selama proses fermentasi, sehingga kadar unsur karbon yang dihasilkan rendah (Suriawiria, 2003; Sutanto, 2002; Yulipriyanto, 2010).

Selain itu, adanya penambahan molase dalam formula pupuk menyebabkan mikroorganisme dekomposer lebih cepat dalam mendegradasi gula (molase) dibandingkan bahan organik utama yaitu ampas jamu dan limbah ikan karena susunannya yang lebih kompleks sehingga jumlah karbon sederhana yang dihasilkan dari perombakan gula tersebut sudah memenuhi kebutuhan karbon mikroorganisme yang menyebabkan bahan utama lebih lama untuk didegradasi (Lestari dkk., 2011).

Hasil kadar unsur nitrogen (Tabel 1) menunjukkan hanya pupuk perlakuan PB yang hampir mendekati standar SNI-19-7030-2004, sedangkan keempat perlakuan yang lain belum memenuhi standar yang ditetapkan. Kadar nitrogen $(\mathrm{N})$ terendah dimiliki pupuk perlakuan PA yaitu $0,0477 \%$, sedangkan kadar $\mathrm{N}$ tertinggi dimiliki pupuk perlakuan PB.

Tabel 1. Hasil Pengukuran Kadar Unsur Hara Pupuk Cair Organik

\begin{tabular}{|c|c|c|c|c|c|c|c|}
\hline \multirow{2}{*}{$\begin{array}{c}\text { Unsur } \\
\text { Hara }(\%)\end{array}$} & \multicolumn{5}{|c|}{ Perlakuan } & \multirow{2}{*}{$\begin{array}{c}\text { SNI 19- } \\
7030-2004 \\
\end{array}$} & \multirow{2}{*}{$\begin{array}{c}\text { Permentan/ } \\
\text { SR.140/10/2011 }\end{array}$} \\
\hline & $\mathbf{P A}$ & PB & PC & PD & $\mathbf{P E}$ & & \\
\hline $\mathbf{C}$ & $\begin{array}{l}2,88^{\mathrm{a}} \pm \\
0,731\end{array}$ & $\begin{array}{l}2,374^{\mathrm{a}} \pm \\
0,670\end{array}$ & $\begin{array}{l}3,1367^{\mathrm{a}} \pm \\
0,16\end{array}$ & $\begin{array}{l}3,1873^{\mathrm{a}} \pm \\
0,951\end{array}$ & $\begin{array}{l}4,8397^{\mathrm{b}} \pm \\
0,321\end{array}$ & $\geq 9,8-32 \%$ & $\geq 6 \%$ \\
\hline N-Total & $\begin{array}{l}0,0477^{\mathrm{a}} \pm \\
0,018\end{array}$ & $\begin{array}{l}0,3537^{c} \pm \\
0,148\end{array}$ & $\begin{array}{l}0,1170^{\mathrm{ab}} \pm \\
0,005\end{array}$ & $\begin{array}{l}0,0693^{\mathrm{a}} \pm \\
0,005\end{array}$ & $\begin{array}{l}0,2373^{\mathrm{bc}} \pm \\
0,058\end{array}$ & $\geq 0,4 \%$ & $3-6 \%$ \\
\hline $\mathbf{P}_{2} \mathrm{O}_{5}$ & $\begin{array}{l}0,03433^{\mathrm{a}} \pm \\
0,0032\end{array}$ & $\begin{array}{l}0,0430^{\mathrm{a}} \pm \\
0,0035\end{array}$ & $\begin{array}{l}0,1233^{b} \pm \\
0,010\end{array}$ & $\begin{array}{l}0,1023^{c} \pm \\
0,0055\end{array}$ & $\begin{array}{l}0,071^{\mathrm{d}} \pm \\
0,0026\end{array}$ & $\geq 0,10 \%$ & $3-6 \%$ \\
\hline $\mathbf{K}_{2} \mathrm{O}$ & $\begin{array}{l}0,18667^{\mathrm{a}} \pm \\
0,0058\end{array}$ & $\begin{array}{l}0,2167^{\mathrm{bc}} \pm \\
0,0058\end{array}$ & $\begin{array}{l}0,2433^{\mathrm{d}} \pm \\
0,0058\end{array}$ & $\begin{array}{l}0,2267^{\mathrm{c}} \pm \\
0,0058\end{array}$ & $\begin{array}{l}0,2067^{\mathrm{b}} \pm \\
0,0058\end{array}$ & $\geq 0,2 \%$ & $3-6 \%$ \\
\hline Ca & $\begin{array}{l}0,0204^{\mathrm{a}} \pm \\
0,0015\end{array}$ & $\begin{array}{l}0,0395^{\mathrm{b}} \pm \\
0,0039\end{array}$ & $\begin{array}{l}0,1369^{d} \pm \\
0,0083\end{array}$ & $\begin{array}{l}0,0865^{\mathrm{c}} \pm \\
0,0133\end{array}$ & $\begin{array}{l}0,0777^{c} \pm \\
0,0114\end{array}$ & $\leq 25,5 \%$ & - \\
\hline $\mathbf{F e}$ & $\begin{array}{l}0,0019^{\mathrm{d}} \pm \\
0,0004\end{array}$ & $\begin{array}{l}0,0002^{\mathrm{a}} \pm \\
0,000\end{array}$ & $\begin{array}{l}0,0007^{b} \pm \\
0,000\end{array}$ & $\begin{array}{l}0,0013^{\mathrm{c}} \pm \\
0,0001\end{array}$ & $\begin{array}{l}0,0003^{\mathrm{a}} \pm \\
0,000\end{array}$ & $\leq 2 \%$ & $0,009-0,09 \%$ \\
\hline Mg & $\begin{array}{l}0,0208^{\mathrm{d}} \pm \\
0,0066\end{array}$ & $\begin{array}{l}0,0129^{\mathrm{a}} \pm \\
0,0005\end{array}$ & $\begin{array}{l}0,0168^{\mathrm{ab}} \pm \\
0,0007\end{array}$ & $\begin{array}{l}0,0153^{\mathrm{ab}} \pm \\
0,0011\end{array}$ & $\begin{array}{l}0,0137^{\mathrm{a}} \pm \\
0,0012\end{array}$ & $\leq 0,6 \%$ & - \\
\hline Keterang & $\begin{array}{l}\text { PA (10 } \\
\text { PB }(10\end{array}$ & $\begin{array}{l}\% \text { ampas jam } \\
\% \text { limbah ika }\end{array}$ & & $\begin{array}{l}50 \% \mathrm{amp} \\
(75 \% \mathrm{amp} \\
(25 \% \mathrm{amp}\end{array}$ & $\begin{array}{l}\mathrm{mu}: 50 \% \\
\mathrm{mu}: 25 \% \\
\mathrm{mu}: 75 \%\end{array}$ & $\begin{array}{l}\text { bah ikan) } \\
\text { bah ikan) } \\
\text { bah ikan) }\end{array}$ & \\
\hline
\end{tabular}


Tingginya kadar nitrogen berasal dari bahan utama pupuk yang digunakan yaitu limbah ikan yang tinggi protein akan didekomposisi oleh mikroorganisme menjadi unsur sederhana seperti amonia, amonium, nitrat, nitrit, dan nitrogen sehingga dapat diserap oleh tanaman (Buckman dan Brandy, 1982 dalam Sukawati, 2010). Selain limbah ikan, ampas kunyit dan beras giling juga memiliki kadar protein berturut-turut sebesar 0,88\% dan 6,8\% (Erniasih dan Saraswati, 2006).

Kandungan nitrogen yang rendah dapat disebabkan unsur nitrogen digunakan oleh mikrooganisme untuk kebutuhan hidupnya dan adanya perubahan unsur nitrogen menjadi bentuk gas (Lestari dkk., 2011). Faktor lain yang memengaruhi tinggi rendahnya kandungan nitrogen yaitu sifat bahan yang digunakan, jenis mikrobia yang tumbuh dan membantu proses fermentasi, kondisi fermentasi, dan lama waktu fermentasi (Marsiningsih, 2015 dalam Marlina, 2016).

Kadar unsur fosfor (P) pupuk cair organik (Tabel 1) yang telah memenuhi standar SNI-197030-2004 yaitu pupuk dengan perlakuan PC dan PD, sedangkan ketiga perlakuan lainnya yaitu PA, PB, dan PE belum memenuhi standar baku mutu minimal yang telah ditetapkan. Kadar fosfor terendah dimiliki oleh perlakuan PA yaitu $0,03433 \%$ sedangkan kadar fosfor tertinggi dimiliki oleh perlakuan PC yaitu $0,123 \%$.

Tingginya unsur $\mathrm{P}$ berasal dari perombakan bahan organik selama proses fermentasi seperti ampas kunyit yang mengadung fosfor sebesar $0,211 \%$, beras sebesar $140 \mathrm{mg} / 100 \mathrm{~g}$, dan ikan sebesar 0,73\% (Card dkk., 2008). Penurunan kadar fosfor dapat terjadi karena fosfor juga dibutuhkan oleh mikroorganisme sebagai sumber nutrisi makro untuk pertumbuhan dan perkembangannya (Indriani dkk., 2013).

Faktor yang memengaruhi tinggi rendahnya kadar fosfor yaitu ketidakseimbangan sumber energi, jumlah nitrogen, dan kandungan bahan baku pupuk cair organik tersebut (Marlina, 2016).

Kadar unsur kalium (K) pupuk cair (Tabel 1) menunjukkan hanya pupuk perlakuan PA yang belum memenuhi standar SNI-19-70302004, sedangkan keempat perlakuan lainnya yaitu perlakuan $\mathrm{PB}, \mathrm{PC}, \mathrm{PD}$, dan $\mathrm{PE}$ sudah memenuhi standar baku mutu minimal yang telah ditetapkan. Unsur kalium terendah dimiliki pupuk perlakuan PA yaitu $0,18667 \%$, sedangkan kadar kalium tertinggi dimiliki pupuk perlakuan PC yaitu $0,2433 \%$.

Tingginya unsur kalium berasal dari perombakan bahan organik menjadi unsur yang lebih sederhana oleh mikroorganisme dekomposer. Mikroorganisme akan membantu meningkatkan kandungan kalium melalui proses dekomposisi dengan melepaskan ion $\mathrm{K}^{+}$melalui proses pertukaran kation dan ketika mikroorganisme mati unsur hara tersebut akan ikut dilepaskan ke lingkungan melalui proses pelapukan (Sundari dkk., 2014; Soemamo, 2011 dalam Indriani dkk., 2013).

Sumber kalium juga dihasilkan dari limbah perikanan misalnya berupa jeroan ikan yang memiliki kandungan kalium cukup tinggi (Zahro, 2015 dalam Rochmana dan Ngadiani, 2017). Rendahnya kadar kalium dapat disebabkan karena pupuk perlakuan PA hanya terdiri dari limbah ampas jamu yang tinggi kandungan serat kasarnya sehingga proses dekomposisi belum terjadi secara maksimal, sehingga bahan organik belum semuanya tergradasi (Sundari dkk., 2014),

Hasil yang diperoleh menunjukkan kadar unsur karbon (C), N, P, dan $\mathrm{K}$ masih belum memenuhi standar baku mutu Permentan/SR.140/10/2011 yang telah ditetapkan, sehingga dalam penggunaanya perlu dilakukan penambahan unsur hara untuk memenuhi kebutuhan unsur hara yang dibutuhkan tanaman.

Pupuk cair organik dari kombinasi limbah ampas jamu dan limbah ikan berdasarkan hasil pengukuran (Tabel 1) memiliki kadar kalsium $(\mathrm{Ca})$, besi $(\mathrm{Fe})$, dan magnesium $(\mathrm{Mg})$ telah memenuhi standar baku mutu pupuk organik berdasarkan SNI 19-7030-2004. Kadar kalsium tertinggi dimiliki pupuk perlakuan PC yaitu $0,1369 \%$, sedangkan kadar kalsium terendah dimiliki pupuk perlakuan PA yaitu 0,0204\%. Adanya kadar kalsium dalam pupuk cair organik berasal dari bahan utama seperti limbah ikan, kencur, ampas kunyit, beras, dan tulang ikan (Erniasih dan Saraswati, 2006; Wardani dkk., 2012).

Kadar unsur besi $(\mathrm{Fe})$ tertinggi dimiliki pupuk perlakuan PA yaitu $0,0019 \%$, sedangkan 
kadar unsur besi terendah dimiliki pupuk perlakuan PB yaitu $0,0002 \%$. Adanya kandungan unsur besi dalam pupuk cair organik berasal dari bahan organik utama yang digunakan yaitu limbah ampas jamu yang mengandung unsur besi $(\mathrm{Fe})$ seperti rimpang kencur (Astuti dkk., 1996), air cucian beras dan beras dengan kandungan unsur besi sebesar $0,8 \mathrm{mg} / 100$ gram mg (Direktorat Gizi, 1996).

Kadar unsur magnesium (Mg) tertinggi dimiliki oleh pupuk perlakuan PA yaitu 0,0208\%, sedangkan kadar unsur magnesium terendah dimiliki pupuk perlakuan PB yaitu $0,0129 \%$. Adanya kandungan magnesium dalam pupuk cair organik berasal dari bahan organik utama yang digunakan yaitu limbah ampas jamu yang terdiri dari beberapa bahan yang mengandung unsur magnesium seperti rimpang kencur (Astuti dkk., 1996), dan air cucian beras (Wardia dkk., 2014).

Karakterisasi Isolat Bakteri Pada Pupuk Cair Organik dari Limbah Ampas Jamu dan Limbah Ikan

Proses isolasi bakteri bertujuan untuk melihat jenis bakteri apa saja yang berperan dalam membantu proses pembuatan pupuk cair organik dari kombinasi limbah ampas jamu dan limbah ikan. Isolasi bakteri dalam penelitian dilakukan pada hari ke-15 fermentasi dan hari ke-28 fermentasi yang bertujuan untuk mengetahui jenis bakteri yang berperan dan membandingkan apakah ada persamaan atau perbedan jenis bakteri pada pertengahan dan akhir proses fermentasi.

Isolat bakteri yang didapatkan dari sampel hari ke-15 fermentasi ada 6 isolat bakteri yang diberi kode T1, T3, T4, T5, T6, dan T8, sedangkan untuk sampel hari ke-28 fermentasi ada 7 isolat bakteri yang berhasil dimurnikan dan diberi kode B,C, D, E, F, G, dan H. Hasil karakterisasi isolat bakteri yang didapatkan dari setiap uji dapat dilihat pada Tabel 2.

Hasil karakterisasi isolat bakteri (Tabel 2) menunjukkan kelompok bakteri Gram positif yaitu isolat T1, T3, T6, T8, C, dan E, sedangkan sisanya termasuk kelompok bakteri Gram negatif. Hampir semua isolat bakteri dapat menghasilkan enzim katalase kecuali isolat T4 dan E.
Isolat yang didapatkan mampu menfermentasi glukosa, kecuali isolat T5. Beberapa isolat yang tidak mampu menfermentasi sukrosa yaitu isolat T4, T5, B, dan $\mathrm{G}$, sedangkan isolat yang tidak mampu menfermentasi laktosa yaitu T5, C, G, dan H. Semua isolat bakteri mampu memecah asam amino triptofan sehingga dapat membentuk cincin indol, serta beberapa diantaranya yaitu isolat $\mathrm{T} 3, \mathrm{~B}, \mathrm{~F}$, dan $\mathrm{H}$ mampu mereduksi senyawa nitrat menjadi nitrit.

Hasil uji yang didapatkan dianalisis secara manual dengan membandingkan data hasil uji yang telah dilakukan dengan di buku Bergey's Manual of Determinative Bacteriologi 7th Edition (Breed dkk., 1957).

Berdasarkan hasil analisis dapat diketahui bahwa Isolat T1 memiliki karakter yang menyerupai karakter bakteri genus Bacillus sp., isolat T3 memiliki karakter yang menyerupai karakter bakteri genus Lactobacillus sp. isolat T4 dan T5 memiliki karakter yang menyerupai karakter bakteri genus Pseudomonas sp., tetapi beda spesies, sedangkan isolat T6 dan T8 memiliki karakteri yang menyerupai bakteri genus karakter Bacillus sp.

Isolat B memiliki karakter yang menyerupai karakter bakteri genus Zymomonas sp., isolat C memiliki karakter yang menyerupai karakter bakteri genus Staphylococcus sp., isolat D memiliki karakter yang menyerupai karakter bakteri genus Actinobacillus sp., isolat E memiliki karakter yang menyerupai karakter bakteri genus Bacillus sp., isolat F memiliki karakter yang menyerupai karakter bakteri genus Cellulomonas sp., isolat $\mathrm{G}$ memiliki karakter yang menyerupai karakter bakteri genus Acetobacter sp., isolat $\mathrm{H}$ memiliki karakter yang menyerupai bakteri genus Pseudomonas sp.

Adanya karakter isolat bakteri yang berbeda tetapi masuk dalam kategori karakter genus bakteri yang sama dikarenakan genus bakteri terdiri dari banyak spesies yang setiap spesies memiliki karakter berbeda, sehingga dimungkinkan bahwa satu genus bakteri memiliki karakter yang beraneka ragam (Breed dkk., 1957).

Isolat bakteri sampel hari ke-15 dan hari ke-28 fermentasi menunjukkan adanya bakteri dengan karakter yang menyerupai karakter dari bakteri genus genus Bacillus sp., dan 
Pseudomonas sp. Hal tesebut menandakan bahwa genus bakteri tersebut berperan penting dalam proses fermentasi terutama proses degradasi bahan organik. Beberapa isolat bakteri sampel hari ke-15 fermentasi tidak ditemukan kembali pada isolasi sampel 28 hari fermentasi dimungkingkan karena jumlah bakterinya yang telah berkurang sehingga pertumbuhannya terbatas, bakteri telah mencapai fase kematian, beberapa bakteri bekerja secara bergantian sehingga untuk proses selanjutnya akan diteruskan oleh genus bakteri yang lain.

Hasil tersebut sesuai dengan penelitian Lopetcharat dkk. (2001) dan Ingratubun dkk. (2013), bahwa kelompok besar bakteri yang terlibat dalam proses fermentasi ikan yaitu bakteri proteolitik seperti bakteri Bacillus sp., Pseudomonas sp. Staphylococcus sp., Halococcus sp., Halobacterium sp., dan Lactobacillus sp. Kelompok bakteri yang mampu mendegradasi limbah jamu menurut hasil penelitian Ariyanti (2011), yaitu kelompok bakteri genus Pseudomonas sp., Acinebacter sp., dan Arthrobacter sp. serta kelompok bakteri selulolitik yang mempu mendegradasi selulosa dan hemiselulosa sehingga menjadi struktur yang lebih sederhana seperti Cellulomonas, Trichoderma, Aspergillus, Clostridium, Penicillium, Neurospora, Fusarium.

Tabel 2. Hasil Karakterisasi dan Uji Biokimia Isolat Bakteri Sampel Fermentasi hari ke-15 dan hari ke-28

\begin{tabular}{|c|c|c|c|c|c|c|c|c|c|c|c|c|}
\hline Isolat & Warna & Tepi & Elevasi & $\begin{array}{c}\text { Bentuk } \\
\text { Sel }\end{array}$ & P.G & Kat & Mtl & G & $\mathbf{S}$ & $\mathbf{L}$ & $\begin{array}{c}\text { R. } \\
\text { Nitrat }\end{array}$ & Indol \\
\hline T1 & Putih susu & Entire & Flat & $\operatorname{Rod}$ & + & + & + & + & + & + & - & + \\
\hline T3 & Putih susu & Entire & Flat & $\operatorname{Rod}$ & + & + & + & + & + & + & + & + \\
\hline T4 & $\begin{array}{l}\text { Kuning tepi } \\
\text { transparan }\end{array}$ & Entire & Convex & Coccus & - & - & - & + & - & + & - & + \\
\hline T5 & $\begin{array}{l}\text { Putih susu tepi } \\
\text { transparan }\end{array}$ & Entire & Raised & Coccus & - & + & + & - & - & - & - & + \\
\hline T6 & Putih susu & Entire & Flat & Rod & + & + & + & + & + & + & - & + \\
\hline T8 & Putih susu & Entire & Raised & $\operatorname{Rod}$ & + & + & + & + & + & + & - & + \\
\hline B & Putih & Entire & Raised & Coccus & - & + & + & + & - & + & + & + \\
\hline $\mathbf{C}$ & Putih susu & Entire & Flat & Coccus & + & + & - & + & + & - & - & + \\
\hline D & Transparan & Gerigi & Flat & Coccus & - & + & + & + & + & + & - & + \\
\hline $\mathbf{E}$ & Kekuningan & Entire & Flat & Basil & + & - & + & + & + & + & - & + \\
\hline $\mathbf{F}$ & Kuning & Entire & Flat & Coccus & - & + & + & + & + & + & + & + \\
\hline $\mathbf{G}$ & Putih keruh & Entire & Raised & Coccus & - & + & - & + & - & - & - & + \\
\hline $\mathbf{H}$ & Putih keruh & Entire & Convex & Coccus & - & + & + & + & + & - & + & + \\
\hline \multicolumn{2}{|c|}{ Keterangan : } & \multicolumn{3}{|c|}{$\begin{array}{l}(+) \text { : Hasil Uji Positif } \\
(-) \text { : Hasil Uji negatif } \\
\text { P.G : Pengecatan Gram } \\
\text { R. nitrat : Reduksi nitrat }\end{array}$} & & \multicolumn{3}{|c|}{$\begin{array}{l}\mathrm{G}: \text { Glukosa } \\
\mathrm{S}: \text { Sukrosa } \\
\text { L : Laktosa } \\
\text { Kat : katalase }\end{array}$} & & \multicolumn{2}{|c|}{ Mtl : Motil } & \\
\hline
\end{tabular}

\section{Simpulan dan Saran}

\section{Simpulan}

Pupuk cair organik dari kombinasi limbah ampas jamu dan limbah ikan memiliki kadar unsur $\mathrm{Fe}, \mathrm{Mg}$, serta $\mathrm{Ca}$ telah memenuhi standar baku mutu SNI-19-7030-2004. Kadar unsur C tertinggi sebesar $4,8397 \%$ yang dimiliki perlakuan PE, kadar N tertinggi yaitu $0,3537 \%$ dimiliki perlakuan $\mathrm{PB}$, sedangkan kadar $\mathrm{P}$ dan $\mathrm{K}$ tertinggi secara berturut-turut yaitu $0,1233 \%$ dan $0,2433 \%$ yang dimiliki perlakuan PC.

Isolat bakteri yang ditemukan dalam pupuk cair organik dari kombinasi limbah ampas jamu dan limbah ikan yaitu isolat bakteri dengan karakter menyerupai karakter bakteri genus Lactobacillus sp., Pseudomonas sp., dan Bacillus sp., Zymomonas sp., Staphylococcus sp., Actinobacillus sp., Cellulomonas sp., dan Acetobacter sp. 


\section{Saran}

Perlu adanya penambahan bahan yang kaya unsur nitrogen dan karbon untuk meningkatkan kadar unsur hara, dan penambahan parameter uji untuk melengkapi data unsur hara, serta perlu dilakukan karakterisasi dan identifikasi lebih lanjut untuk memastikan genus bakteri yang didapatkan.

\section{Ucapan Terima Kasih}

Terima kasih kepada Pemerintah Indonesia yang telah memberikan beasiswa pendidikan selama masa studi sehingga penelitian ini pun dapat berjalan dengan lancar.

\section{Daftar Pustaka}

Aditya, S., Suparmi dan Edison. 2015. Studi pembuatan pupuk organik padat dari limbah perikanan. Skripsi S1. Fakultas Pertanian dan Ilmu Kelautan. Universitas Riau, Riau.

Ariyanti, S.B. 2011. Penurunan kadar fenol pada kasus limbah industri jamu dengan metode lumpur aktif secara anaerob. Jurnal Biopropal industri, 2 (1): 14-20.

Astuti, Y., Sundari, D. dan Winarno, M.W. 1996. Tanaman kencur (Kaempferia galanga L.); informasi tentang fitokimia dan efek farmakologi. Warta Tumbuhan Obat Indonesia, 3 (2): 1.

Atmaka, W., Manuhara, G.J., Destiana, N., Kawiji., Khasanah, L.U. dan Utai, R. 2016. Karakterisasi pengemas kertas aktif dengan penambahan oleoresin dari ampas pengepresan rimpang temulawak (Curcuma xanthorrhiza Roxb). Reaktor, 16 (1): 32-40.

Breed, R.S., Murray, E.G.D. dan Smith, N.R. 1957. Bergey's Manual of Determinative Bacteriology 7th Edition. The Williams and Wilkins Company, USA. Hal. 613, 601.

Card, A., Whiting, D., Wilson, C. dan Reeder, J. 2008. Organic fertilizers. Colorado State University Extension.

Dewi, N.K., Kiswardianata, R.B. dan Huriawati, F. 2016. Pemanfaatan seresah lamun (seagrass) sebagai bahan baku pupuk organik cair. Proceeding Biology Education Conference, 13 (1): 649-652.

Direktorat Gizi Departemen Kesehatan RI. 1996. Daftar Komposisi Bahan Makanan. Bhartara Karya Aksara, Jakarta.
Erniasih, I. dan Saraswati, T.R. 2006. Penambahan limbah padat kunyit (Curcuma domestica) pada Ransum Ayam dan Pengaruhnya terhadap Status Darah dan Hepar Ayam (Gallus sp). Buletin Anatomi dan Fisiologi, 15 (2): 1-6.

Handayani, S.H., Yunus, A. dan Susilowati, A. 2015. Uji kualitas pupuk organik cair dari berbagai macam mikroorganisme lokal (MOL). El-Vivo, 3 (1): 54-60.

Indiani, F., Sutrisno, E. dan Sumiyati, S. 2013. Studi pengaruh penambahan limbah ikan pada proses pembuatan pupuk cair dari urin sapi terhadap kandungan unsur hara makro (CNPK). Jurnal Teknik Lingkungan, Volume 2 (2) : 1-8.

Ingratubun, J.A., Ijong, F.G. dan Onibala, H. 2013. Isolation and identification of lactic acid bacteria in Bakasang as fermented microbe starter. Aquatic science and Management, 1: 4856.

Lestari, I.P., Satro, Y. dan Irawati, A.F.C. 2011. Kajian Teknologi Fermentasi Limbah Ikan Sebagai Pupuk Organik. Balai Pengkajian Teknologi Pertanian Jakarta, Jakarta.

Lopetcharat, K., Choi, Y.J., Park, J.W. dan Daeschel, M.A. 2001. Fish sauce products and manufacturing. A review. Food Research International, 17: 6568.

Marlina, S. 2016. Analisis N dan P pupuk organik cair kombinasi daun lamtoro limbah tahu dan feses sapi. Publikasi Ilmiah. Program Studi Pendidikan Biologi. Fakultas Ilmu Pendidikan Ilmu Pengetahuan. Universitas Muhammadiyah Surakarta, Surakarta.

Natalia, D., Suprijatna, E. dan Muryani, R. 2016. Pengaruh penggunaan limbah industri jamu dan bakteri asam laktat (Lactobacillus sp.) sebagai sinbiotik untuk aditif pakan terhadap performans ayam petelur periode layer. Jurnal Ilmu-Ilmu Peternakan, 2 (3): 6-13.

Rochmana, N.F. dan Ngadiani. 2017. Uji banding limbah cair ikan, Azolla, dan limbah kulit pisang sebagai nutrisi tambahan untuk kualitas poduksi tanaman cabai rawit (Capsium frutencens L.). Sigma, 10 (2): 16-24

Santi, S.S. 2008. Kajian pemanfaatan limbah nilam untuk pupuk cair organik dengan proses fermentasi. Jurnal Teknik Kimia, 2 (2): 170-174.

Siboro, E.S., Surya, E. dan Herlina, N. 2013. Pembuatan pupuk cair dan biogas dari campuran limbah sayuran. Jurnal teknik kimia USU, 2 (1): 40-43.

Sukawati, I. 2010. Pengaruh kepekatan larutan nutrisi organik terhadap pertumbuhan dan hasil baby kailan (Brassica oleraceae var. albo-glabra) pada berbagai komposisi media tanam dengan sistem hidroponik substrat. Skripsi S1. Fakultas 
Jumirah dkk.,

Pertanian. Universitas Sebelas Maret Surakarta, Surakarta.

Sundari, I., Maruf, W. F. dan Dewi, E. N. 2014. Pengaruh penggunaan bioaktivator EM4 dan penambahan tepung ikan terhadap spesifikasi pupuk organik cair rumpul laut Gracilaria sp. Jurnal Pengolahan dan Bioteknologi Hasil Perikanan, 3 (3): 88-94.

Suriawiria, U. 2003. Mikrobiologi Air dan Dasar-Dasar Pengolahan Buangan Secara Biologis. PT Alumni, Bandung.

Sutanto, R. 2002. Penerapan Pertanian Organik. Kanisius, Yogyakarta.

Wardani, D.P., Liviawaty, E. dan Junianto. 2012. Fortifikasi tepung tulang tuna sebagai sumber kalsium terhadap tingkat kesukaan donat. Jurnal Perikanan dan Kelautan, 3 (4): 41-50.

Wardiah, Linda dan Rahmatan, H. 2014. Potensi limbah air cucian beras sebagai pupuk organik cair pada pertumbuhan pakchoy (Brassica rapa L.). Jurnal Biologi Edukasi, 6 (1): 34-38.

Yulipriyanto, H. 2010. Biologi Tanah dan Startegi Pengolahannya. Graha Ilmu, Yogyakarta. 